\title{
HUBUNGAN PENGGUNAAN MEDIA PEMBELAJARAN DENGAN KONSEP DIRI
}

\author{
Lina Novita $^{\left.a^{*}\right)}$, Elly Sukmanasa ${ }^{a)}$, Devi Cahya ${ }^{a)}$ \\ ${ }^{a)}$ Universitas Pakuan, Bogor, Indonesia \\ *) e-mail korespondensi : linovtaz@gmail.com
}

Riwayat Artikel : diterima: 05 Januari 2020; direvisi: 19Januari 2020; disetujui: 26 Januari 2020

\begin{abstract}
Abstrak. Penelitian ini bertujuan untuk mengetahui hubungan penggunaan media pembelajaran dengan konsep diri. Pendekatan penelitian menggunakan kuantitatif dengan metode studi korelasional. Data penelitian diperoleh dengan menggunakan instrument angket untuk kedua variabel. Uji validitas instrumen penggunaan media pembelajaran dan konsep diri dihitung menggunakan rumus Product Moment Pearson dan untuk koefisien reliabilitas dihitung dengan rumus Alpha Cronbach. Populasi terdiri dari siswa kelas VA,VB, dan VC Sekolah Dasar Negeri Pengadilan 2 berjumlah 94 siswa. Sampel 48 siswa yang diperoleh menggunakan rumus Taro Yamane. Pengujian prasyarat analisis berupa uji normalitas (Liliefors). Setelah dari uji normalitas kemudian dilakukan pengujian homogenitas (Fisher). Data yang sudah dinyatakan normal dan homogen digunakan untuk menguji hipotesis yang hasilnya menunjukan bahwa penggunaan media pembelajaran memiliki hubungan yang positif dan signifikan dengan konsep diri. Analisis statistik menghasilkan koefisien korelasi (rxy) sebesar 0,69, artinya tingkat hubungan tergolong kuat dan diperoleh thitung sebesar 8,80 lebih besar dari ttabel dengan taraf nyata 0,05 sebesar 2,021 yang berarti signifikan. Dengan demikian, dapat disimpulkan bahwa terdapat hubungan yang positif dan signifikan penggunaan media pembelajaran dengan konsep diri siswa.
\end{abstract}

Kata Kunci: media pembelajaran; konsep diri

\section{RELATIONSHIP USING LEARNING MEDIA WITH SELF CONCEPT}

Abstract. The aim of this study is to determine the relationship between the use of learning media and self-concept. The research approach uses quantitative with correlational study methods. The study data was obtained using a questionnaire tool for both variables. The validity test of the use of instructional media and self-concept tools was calculated using the Pearson Product Moment formula and the reliability coefficient was calculated using the Cronbach Alpha formula. The population consisted of VA, VB and VC students from the District 2 Primary School. A sample of 48 students was obtained using the Taro Yamane formula. Testing the analysis requirements in the form of normality tests (Liliefors). After the normality test is performed, a homogeneity test is then performed (Fisher). Data declared normal and homogeneous are used to test hypotheses, the results of which indicate that the use of instructional media has a positive and significant relationship with self-concept. Statistical analysis yields a correlation coefficient (rxy) of 0.69, which means that the relationship level is classified as strong and a count of 8.80 is higher than ttable with a significant level of 0.05 of 2.021, meaning significant. It can therefore be concluded that there is a positive and significant relationship between the use of instructional media and the self-concepts of students.

Keywords: learning Media; self concept.

\section{PENDAHULUAN}

Media pembelajaran sudah selayaknya digunakan dalam pembelajaran, karena media merupakan salah satu alat yang digunakan untuk memperjelas informasi yang disampaikan pendidik dalam pembelajaran. Sebagai alat bantu, media diartikan sebagai bagian yang tidak terpisahkan dan tentu saja harus sesuai dengan proses pembelajaran secara menyeluruh [1]. Dengan kata lain pemilihan media sebagai alat pembelajaran memungkinkan peserta didik dapat berinteraksi dengan media yang dipilih.

Penggunaan media pembelajaran menurut Sukmanasa, dkk. [2] dapat meningkatkan kemampuan siswa. pemahaman materi yang disampaikan oleh guru. Pendapat tersebut memiliki kesamaan dengan Novita [3] bahwa media pembelajaran memegang peranan penting untuk menarik minta siswa dalam belajar. Hal demikian mendorong upayaupaya pemanfaatan hasil teknologi ke dalam proses belajar mengajar. Salah satunya adalah media pembelajaran berbasis ICT (Information and Communication Technology) sehingga menciptakan suasana penyampaian dan pemahaman materi yang lebih bersemangat dan menyenangkan.

Namun kenyataannya, penggunaan media masih kurang maksimal digunakan oleh pendidik dalam hal ini guru baik di lingkungan sekolah dasar, maupun menengah. Kondisi tersebut dapat diakibatkan karena kemampuan guru maupuan sarana prasarana di sekolah. Kenyataan ini dapat dilihat dari hasil penelitian Novita [4] yang menunjukkan bahwa penggunaan media pembelajaran terutama yang berbasis TIK, ada pada kategori rendah. Hal tersebut membuktikan belum adanya kesadaran akan pentingmya media pembelajaran dalam proses belajar.

Temuan data hasil observasi yang dilakukan kepada 94 siswa Sekolah Dasar Negeri Pengadilan 2 kelas V diketahui bahwa sekitar 32\% siswa memiliki sikap kurang peduli pada proses pembelajaran, $47 \%$ siswa belum sepenuhnya paham tentang materi pelajaran, $21 \%$ siswa kurang memiliki interaksi yang baik pada proses pembelajaran. penggunaan media. Kondisi ini diketahui 
pada saat salah seorang guru Penggunaan media pembelajaran diharapkan dapat menumbuhkan sikap siswa dalam belajar. Artinya siswa memiliki konsep diri yang baik ketika pembelajaran berlangsung. Konsep diri diperlukan siswa, karena dengan konsep diri yang baik siswa dapat menerima pembelajaran dengan baik. Konsep diri memliki peranan dalam pembentukan sikap siswa baik pada saat belajar di sekolah maupun di lingkungan keluarga, dan masyarakat. Oleh sebab itu perlu kiranya guru menumbuhkan konsep diri yang positif pada diri siswa.

Berkaitan dengan konsep diri, telah banyak penelitian yang dilakukan, salah satunya penelitian Ambarwati [5] yang membuktikan bahwa 67,74\% siswa memiliki konsep diri sedang. Hal ini menunjukkan rata-rata siswa memiliki konsep diri yang cukup baik. Konsep diri siswa pada masa ini berkembang ke arah yang lebih ideal dan berubah sesuai perkembangannya.

Memahami media pembelajaran paling tidak ditinjau dari dua aspek, yaitu pengertian bahasa dan pengertian terminology. Kata media berasal dari bahasa latin dan merupakan bentuk jamak dari kata medium yang secara harfiah berarti „perantara" atau „pengantar". Kata kunci media adalah "perantara". Pengertian media secara terminology cukup beragam, sesuai sudut pandang para pakar media pendidikan. Daryanto [6] mengemukakan bahwa media pembelajaran merupakan faktor yang dapat memotivasi siswa dalam melaksanakan pembelajaran dan mampu mendorong siswa untuk mencapai hasil belajar yang maskimal. Sementara itu, Gagne dan Briggs dalam Arsyad [7] mengatakan bahwa secara implisit mengatakan bahwa media pembelajaran meliputi alat yang secara fisik digunakan untuk menyampaikan isi materi pengajaran, yang terdiri dari antara lain buku, tape recorder, kaset, video camera, video recorder, film, dan slide (gambar bingkai), foto, gambar, grafik, televisi dan komputer. Sedangkan Adam [8] menyatakan dalam jurnalnya bahwa media pembelajaran adalah segala sesuatu baik berupa fisik maupun teknis dalam proses pembelajaran yang dapat membantu guru untuk mempermudah dalam menyampaikan materi pelajaran kepada siswa sehingga memudahkan pencapaian tujuan pembelajaran yang telah dirumuskan.

Dari pendapat para ahli di atas, dapat disintesiskan bahwa media merupakan alat bantu atau perantara dalam pembelajaran. Alat bantu yang digunakan guru untuk memotivasi siswa dalam pembelajaran.

Selanjutnya seperti telah disinggung di atas siswa memerlukan konsep diri, karena mereka dapat secara tidak langsung mengenal pribadi mereka masing-masing. Dalam hal ini Agustiani [9] menyatakan konsep diri merupakan gambaran yang dimiliki seseorang tentang dirinya, yang dibentuk melalui pengalaman-pengalaman yang diperoleh dari interaksi dengan lingkungan. Senada dengan pendapat di atas Gufron, dkk [10] menyatakan bahwa konsep diri adalah apa yang dirasakan dan dipikirkan oleh seseorang mengenai dirinya sendiri. komponen kognitif mencangkup pengetahuan individu tentang dirinya "siapa saya" yang akan memberikan gambaran tentang diri saya, komponen afektif merupakan penilaian individu terhadap diri sendiri yang akan membentuk bagaimana penerimaan terhadap diri dan harga diri individu.

Sementara itu Menurut Marcer [11] konsep diri dipandang sebagai representasi kognitif diri yang berupaya memberikan koherensi dan makna bagi pengalamanpengalaman kita, bagaimana diri diorganisasikan, dipelihara, dan dapat mengatur perilaku kita. Lebih lanjut, menurut Surya [12] konsep diri merupakan inti pola-pola kepribadian yang menjadi landasan bagi perwujudannya di lingkungan kehidupan konsep diri merupakan gambaran pandangan mengenai diri sendiri yang bersumber dari satu perangkat keyakinan dan sikap terhadap dirinya sendiri.

Sebagai suatu pembentukan sikap, konsep diri tidak terlepas dari beberapa faktor pembentuknya. Beberapa pendapat Rakhmat [13] menyebutkan faktor yang mempengaruhi konsep diri adalah peranan orang lain dalam memahami diri sendiri. Adapun menurut Ubaedy [14] konsep diri itu dibangun yaitu: 1) Faktor Eksternal ini merupakan faktor yang dipengaruhi oleh ungkapan seseorang. 2) Faktor Internal merupakan konsep diri yang dibangun dari faktor internal ini sifatnya bukan lagi pilihan, melainkan kepastian. Seiring dengan pertumbuhan dan perubahan fisik, kognitif dan kemampuan sosial anak usia sekolah dasar akan mengalami perubahan dalam pandangan terhadap dirinya sendiri dan setiap siswa semakin tumbuh besar akan mempengaruhi terhadap karakternya. Desmita [15] mengutip pendapat Santrock yang menyatakan perubahan-perubahan dalam konsep diri anak selama tahuntahun sekolah dasar.

Pendapat atau kajian teori di atas, dapat disintesiskan bahwa konsep diri merupakan sikap yang unik mengenai gambaran diri sendiri yang dimiliki seseorang tentang dirinya melalui pengalaman-pengalaman dari interaksi yang membedakan manusia dari makhluk lainnya

\section{METODE PENELITIAN}

Penelitian dilaksanakan dengan pendekatan korelasional. Penelitian korelasi ini dilaksanakan pada siswa kelas V SDN Pengadilan 2 Kota Bogor. Dilaksanakan pada semester genap tahun ajaran 2018/2019, penentuan waktu penelitian mengacu pada kalender akademik sekolah. Populasi dalam penelitian ini adalah seluruh siswa kelas V berjumlah 94 siswa. Sampel yang digunakan dalam penelitian dilakukan dengan rumus Taro Yamane. Jumlah sampel penelitian sebanyak 48 orang siswa kelas V. Penelitian bertujuan untuk mengetahui tentang hubungan dua variabel, yaitu variabel bebas (X) dalam penelitian ini adalah penggunaan media pembelajaran dan variabel terikat (Y) yaitu konsep diri,

Teknik pengumpulan data penelitian ini menggunakan metode survei untuk mengumpulkan data dari siswa yang terpilih sebagai responden untuk memperoleh informasi mengenai hubungan penggunaan media pembelajaran dengan konsep diri siswa kelas V di SDN Pengadilan 2 Kota Bogor.

Uji coba instrumen dilakukan pada 46 responden. validitas uji coba instrumen non tes korelasi menggunakan 
rumus Product Moment Pearson. Uji reliabilitas instrumen penelitian menggunakan perhitungan Alpha Cronbach. Sebelum dilakukan uji hipotesis statistik, terlebih dahulu data penelitian harus memenuhi persyaratan analisis dengan menggunakan uji normalitas galat baku taksiran dan uji linearitas regresi. Metode penelitian yang digunakan adalah metode penelitian survei dengan teknik korelasional.

\section{HASIL DAN PEMBAHASAN}

Deskripsi data penelitian ini dikelompokkan menjadi dua bagian, yaitu terdiri dari kelompok data variabel terikat yaitu, konsep diri (Y), dan data variabel bebas, penggunaan media pembelajaran $(\mathrm{X})$ yang dideskripsikan dalam bentuk deskriptif statistik. Deskripsi data masing-masing yaitu skor terendah, skor tertinggi, rentang skor, rata-rata (mean), nilai tengah (median), nilai yang sering muncul (modus), standar deviasi (SD), varians sampel, dan total skor.

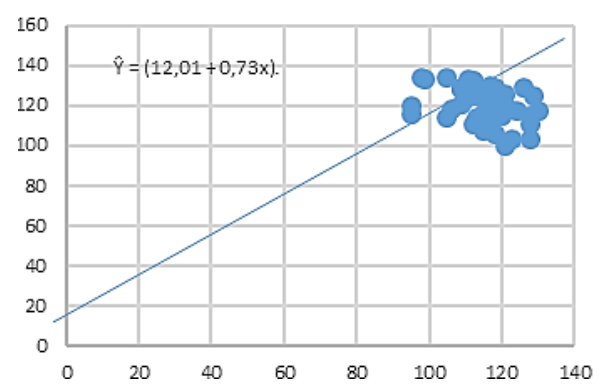

Gambar 1. Diagram Pancar Hubungan Fungsional Variabel penggunaan media pembelajaran $(\mathrm{X})$ dan konsep diri (Y)

Sesuai dengan hasil perhitungan analisis persamaan regresi pada gambar diagram pancar di atas menunjukan suatu korelasi bahwa terdapat hubungan positif dan menunjukan keeratan antara kedua variabel dengan ketentuan korelasi positif variabel Y akan naik jika variabel $\mathrm{X}$ naik, Jika variabel $\mathrm{X}$ dekendalikan maka variabel $\mathrm{Y}$ juga akan dikendalikan. Kebenaran dari hasil regresi di atas digunakan untuk menguji hipotesis mengenai ada tidaknya hubungan positif antara penggunaan media pembelajaran (X) dengan konsep diri siswa (Y). Hubungan fungsional anatara $\mathrm{X}$ dan $\mathrm{Y}$ disajikan dalam bentuk $\hat{\mathrm{Y}}=12,01+0,73 \mathrm{X}$ dengan $\mathrm{X}$ adalah signifikan.

Hasil analisis statistik di atas bahwa Terdapat hubungan yang positif penggunaan media pembelajaran dengan konsep diri siswa. Hal ini berarti bahwa hipotesis penelitian dapat diterima karena penggunaan media pembelajaran memberi kontribusi pada konsep diri siswa. Hasil analisis Product Moment menunjukan koefisien korelasi 0,69. Artinya terdapat korelasi yang sangat tinggi antara penggunaan media pembelajaran dengan konsep diri siswa dan arahnya yang positif. Artinya jika penggunaan media pembelajaran tinggi, maka konsep diri siswa pun akan ikut tinggi dan sebaliknya. Hubungan antara penggunaan media pembelajaran dengan konsep diri siswa sebesar $47 \%$.
Berdasarkan hasil uji signifikan koefisien korelasi diperoleh hasil uji keberartian koefisien korelasi yaitu, penguji hipotesis menggunakan uji korelasi Product Momen Pearson. Hasil analisis menunjukan hubungan positif penggunaan media pembelajaran dengan konsep diri siswa dengan persamaan $\hat{Y}=12,01+0,73 X$. Selanjutnya hasil uji signifikansi diperoleh $t_{\text {hitung }}=8,80$ sedangkan $t_{\text {tabel }}$ dengan $(\alpha=0,05)=2,021$ dan dk 48. Sehingga $t_{\text {hitung }}>t_{\text {tabel }}(\alpha=0,05)$ yaitu $8,80>2,021$. Perbandingan kedua nilai yang diperoleh menunjukan bahwa $t_{\text {hitung }}>t_{\text {tabel }}$ yang menunjukan bahwa penggunaan media pembelajaran (X) dengan konsep diri siswa (Y) signifikan. Karena koefisien korelasi yang diperoleh positif, artinya semakin tinggi penggunaan media pembelajaran semakin tinggi pula konsep diri siswa yang diperoleh. Kekuatan hubungan antara penggunaan media pembelajaran dengan konsep diri siswa ditunjukkan dengan koefisien korelasi sebesar 0,69 Harga koefisien tersebut menunjukan bahwa terdapat hubungan yang sangat kuat penggunaan media pembelajaran dengan konsep diri siswa. Besarnya kontribusi penggunaan media pembelajaran dengan konsep diri siswa ditunjukkan oleh koefisien $\left(\mathrm{r}^{2}\right)$ sebesar 0,47 dengan koefisien determinasi sebesar $47 \%$.

Hasil penelitian ini memiliki kesamaan pendekatan atau metodologi penelitian dengan penelitian yang telah dilakukan Novita [16], namun berbeda dalam variabel yang diteliti. Penelitian yang telah dilakukan oleh Novita, dkk meneliti tentang Hubungan konsep diri dan disiplin siswa pada kelas V. Hasil perhitungan diperoleh nilai koefisien korelasi dengan nilai r 0, 48 yang berarti memiliki hubungan. Kemudian penelitian lainnya yang memiliki relevansi dengan hasil penelitian ini ditemukan pada penelitian Firdaus [17] mengenai pengaruh penggunaan media pembelajaran dan konsep diri terhadap hasil belajar matematika. Penelitian ini berbeda secara metode dan variabel yang diteliti, namun memiliki kesamaan dalam salah satu variabel, yaitu penggunaan media pembelajaran. Hasil penelitian adanya pengaruh media pembelajaran dan konsep diri pada hasil belajar matematika. Penelitian lainnya dilakukan Adawiyah [18] dengan judul hubungan penggunaan media pembelajaran dengan minat belajar siswa. Penelitian ini memiliki kesamaan metode yang digunakan, dan salah satu variabel penggunaan media pembelajaran. Hasil penelitian membuktikan bahwa penggunaan media pembelajaran memiliki hubungan dengan minat siswa dalam belajar.

Merujuk dari hasil penelitian dan penelitian relevan, maka dapat dikatakan bahwa penggunaan media pembelajaran memiliki hubungan baik itu dengan konsep diri maupun dengan variabel lainnya. Dengan demikian media pembelajaran sebaiknya lebih dimaksimalkan penggunaannya dalam pembelajaran.

\section{SIMPULAN}

Berdasarkan hasil pengolahan data, hasil hipotesis dan pembahasan hasil penelitian, maka dapat disimpulkan siswa di SDN Pengadilan 2 memiliki ketertarikan pada pembelajaran dengan menggunakan media pembelajaran. 
Sikap yang merupakan bagian dari konsep diri siswa terlihat pada kegiatan pembekajharan dengan penggunaan media. Konsep diri siswa berkembang sesuai dengan minat yang mucul pada saat pembelajaran dengan menggunakan media. Artinya ada hubungan penggunaaan media pembelajaran dengan konsep diri.

Hubungan tersebut terlihat dari harga koefisien korelasi r sebesar 0,69 yang berarti hubungan antara variabel kuat. Koefisien persamaan regresi $\hat{\mathrm{Y}}=12,01+0,73 \mathrm{X}$ artinya apabila penggunaan media pembelajaran naik satu unit, maka konsep diri siswa akan mengalami peningkatan sebesar 0,73

\section{REFERENSI}

[1] Sutisna, Entis dan Novita, Lina. 2020. Media dalam Pembelajaran. Bogor: PGSD Press.

[2] Sukmanasa, Elly, Novita, Lina, dan Majid, Rifky Abdul. 2019. Use Of Learning Video Media On Human And Environmental Subthema. Journal JHSS. Vol. 3 No. 2. e-ISSN: 2598-120X; p-ISSN: 2598$117 \mathrm{X}$

[3] Novita, Lina, Windiyani, Tustiyana, dan Fazriani, Rifa. 2019. Pengembangan Media Pembelajaran Berbasis ICT. Pada Subtema Bersyukur Atas Keberagaman Untuk Siswa Kelas IV Sekolah Dasar. Jurnal JPPGuseda. Vol. 2 No. 2 e-ISSN: 2623-0232 ; p-ISSN: 2623-0941

[4] Novita, Lina, Windiyani, Tustiyana, dan Fauziah, Siti Sarah. 2020. Analisis Pemanfaatan Media Pembelajaran Berbasis TIK Di Sekolah Dasar Negeri Pengadilan 5 Bogor. JPI (Jurnal Pendidikan Indonesia) UNS. Vol. 6 No.1. 2443-3268

[5] Ambarwati. 2016. Hubungan Konsep Diri dengan Interaksi Sosial Siswa Kelas IV SD" Jurnal Pendidikan Guru Sekolah Dasar. Vol.1(4). h.927.

[6] Daryanto. 2018. Media Pembelajaran. Yogyakarta: Gava Media

[7] Arsyad, A. 2017. Media Pembelajaran. Jakarta. PT Rajagrafindo Persada.

[8] Adam, S. \& Syastra, M.T. 2015. Pemanfaatan Media Pembelajaran Berbasis Teknologi Informasi Bagi Siswa Kelas X SMA Ananda Batam. Jurnal: CBIS Journal, 3 (2), hlm. 78-90.

[9] Agustiani. 2009. Psikologi Perkembangan. Bandung: Refika

[10] Gufron,Nur. 2012. Teori-teori Psikologi. Jogjakarta: Ar-Ruzz Media

[11] Marcher, Jenny. dkk. 2012. Psikologi Sosial. Jakarta: Erlangga

[12] Surya, Moch. 2013. Psikologi Guru Konsep dan Aplikasi. Bandung: Alfabeta.

[13] Rakhmat. 2011. Psikologi Komunikasi. Bandung: Remaja

[14] Ubaedy. 2013. Total confidence. Jakarta: Bee Media Pustaka

[15] Desmita. 2016. Psikologi Perkembangan Peserta Didik. Bandung: Remaja
[16] Novita, Lina. 2019. Hubungan antara Konsep Diri Dan Disiplin Siswa Pada Siswa kelas V di SDN Kota Batu 02 Kecamatan Ciomas Kabupaten Bogor". Jurnal Pendidikan \& Pengajaran Guru Sekolah Dasar. Vol.2, (1).

[17] Firdaus, Indra Cahya. 2019. Pengaruh Penggunaan Media Pembelajaran dan Konsep Diri Siswa Terhadap Hasil Belajar Matematika Siswa. DOI: 10.32493/informatika.v2i1.1505

[18] Adawiyah, Silmi Siti Rabiatul. 2018. Hubungan Penggunaan Media Pembelajaran dengan Minat Belajar Siswa Pada Mata Pelajaran Fiqih Kelas Iv Mi Al Madani Tajur Halang Kab. Bogor. DOI: 10.32507/attadib.v1i2.23 